einstein

Official Publication of the Instituto Israelita

de Ensino e Pesquisa Albert Einstein

ISSN: 1679-4508 | e-ISSN: 2317-6385

\title{
Endobronchial ultrasound: a minimally invasive technology to assist diagnosis of thoracic diseases
}

\section{Ultrassonografia endobrônquica: tecnologia minimamente invasiva para auxiliar no diagnóstico de doenças torácicas}

\author{
Altair da Silva Costa Jr. ${ }^{1}$, Addy Lidvina Mejia Palomino', lunis Suzuki', \\ Paulo Rogerio Scordamaglio', Marcelo Gervilla Gregorio', Marcia Jacomelli' \\ 1 Hospital Israelita Albert Einstein, São Paulo, SP, Brazil.
}

DOI: 10.31744/einstein_journal/2019MD4921

\section{ABSTRACT}

The endobronchial ultrasound is a minimally invasive technique that simultaneously associates ultrasound and bronchoscopy, to visualize lung nodule or masses, airway wall, and structures adjacent to the tracheobronchial tree. Endobronchial ultrasound has been incorporated into clinical practice all over the world because of its low risk and high diagnostic yield in neoplastic and non-neoplastic disease.

Keywords: Mediastinum; Biopsy, fine-needle; Endoscopic ultrasound-guided fine needle aspiration/ methods; Ultrasonography, interventional; Lymph nodes; Bronchoscopy

\section{RESUMO}

A ultrassonografia endobrônquica é uma técnica minimamente invasiva que associa simultaneamente broncoscopia à ultrassonografia, com a finalidade de visualizar nódulos ou massas pulmonares, paredes das vias aéreas, e estruturas ao redor de toda a árvore traqueobrônquica. A ultrassonografia endobrônquica foi incorporada à prática clínica em todo o mundo devido a seu baixo risco e elevado rendimento diagnóstico em doenças neoplásicas e não neoplásicas.

Descritores: Mediastino; Biópsia por agulha fina; Aspiração por agulha fina guiada por ultrassom endoscópico/métodos; Ultrassonografia de intervenção; Linfonodos; Broncoscopia

\section{INTRODUCTION}

Since it was introduced by Hurter and Hanrath, in 1992, endobronchial ultrasound (EBUS) has been a useful technique that allows the bronchoscopist to see beyond the airways, including airway wall, lung and mediastinum. Endobronchial ultrasound is performed during bronchoscopy and permits sample collection for different thoracic disease. There are two types of EBUS: convex-probe EBUS (CP-EBUS) and radial-probe (RP-EBUS). These technologies will be discussed in the following topics.

\section{Convex endobronchial ultrasound}

The currently available CP-EBUS is a dedicated ultrasound equipment, placed on the tip of a flexible bronchoscope to obtain images of the airways by direct 
contact of the probe with the tracheobronchial wall. The equipment has a working channel, Doppler function and a dedicated needle to perform a safe transbronchial needle aspiration, with ultrasound images, in real-time. The procedure is called EBUS transbronchial needle aspiration (EBUS-TBNA). All lesions near or in contact with the tracheobronchial tree can be accessed by EBUS-TBNA. In this way, the most frequent indications for EBUS-TBNA are diagnosis of mediastinal and hilar lesions of any etiology, mediastinal staging and restaging of lung cancer, staging of extra-thoracic cancer. ${ }^{(1)}$

The needle size varies from 19 to $25 \mathrm{G}$, for histological and cytological, respectively. The needles available in Brazil are for cytological sampling only (21, 22 and $25 \mathrm{G})$.

Especially for mediastinal staging of lung cancer, EBUS-TBNA requires a systematic assessment. In this context, in 2009 the International Association for the Study of Lung Cancer (IASLC) ${ }^{(2)}$ established a mediastinal map and the lymph node stations were numbered from 1 to 14 . The EBUS-TBNA can assess the stations 2, 4, 7, 10, 11 and 12. The assessment of each lymph node station depends on clinical indication, computed tomography (CT) or positron emission tomography CT (PET-CT) findings, and etiology of the tumor. For example, during mediastinal staging of lung cancer, it is mandatory to start from N3 station (from contralateral or mediastinal hilum), followed by $\mathrm{N} 2$ (mediastinal or ipsilateral subcarinal lymph node) and N1 nodes (ipsilateral hilum or lobar) at the end of exam. As we have a large number of lymph node stations to be evaluated, it is necessary to choose the suspected lymph node to be sampled by EBUS-TBNA according to ultrasonographic aspects. Malignant nodes tend to be round, with well-defined margin, heterogeneous, without central hilar structure. Furthermore, it is important to add this information to tomographic or PET-CT analysis. On figure 1, there is an example of a male patient with lung cancer (adenocarcinoma) and a chest tomography with a large lymph node at station 7 . The respective PET-CT showed a SUV of 12.6 and EBUS-TBNA was performed (Figure 2).

Other important factor during EBUS-TBNA is the rapid on-site evaluation (ROSE) by a pathologist, to assess the representativeness of the sample and conduct the detailed specific analysis. ${ }^{(3)}$ The remaining material is placed in formalin for cellblock analysis. Molecular analysis for cancer can be carried out in EBUS-TBNA samples. $^{(3-5)}$ If non-cancer is suspected during ROSE, the sample can be sent to microbiological analysis, flow cytometry or polymerase chain reaction (PCR). The sensitivity of EBUS-TBNA ranges from 84 to $96 \% .^{(4-7)}$

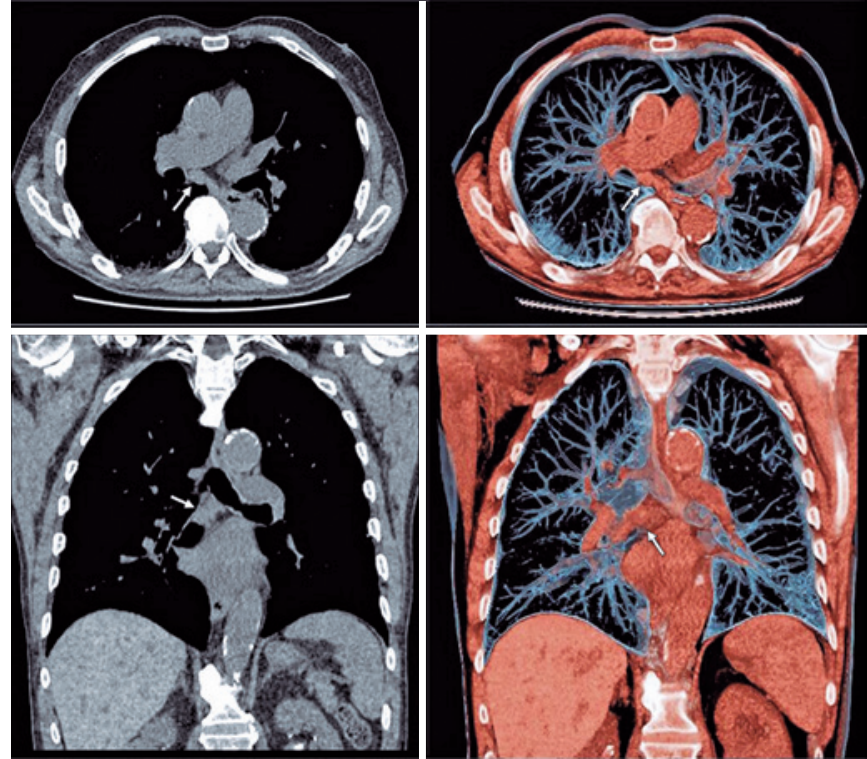

Figure 1. Chest tomography and subcarinal lymph node (station 7 - arrow)
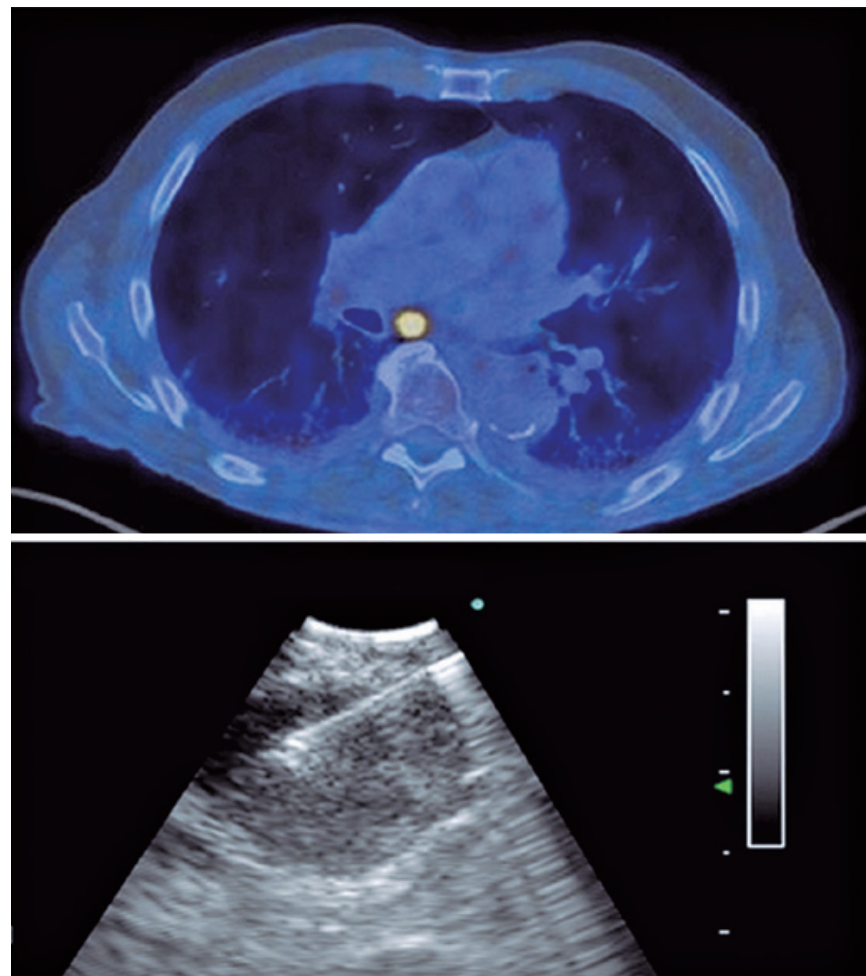

Figure 2. Positron emission tomography (SUV 12.6) and endobronchial ultrasound. Transbronchial needle aspiration with real-time lymph node puncture

\section{Radial-probe endobronchial ultrasound}

Radial-probe EBUS is performed using a $20 \mathrm{mHz}$ flexible delicate probe (UM-3R, Olympus Medical Systems Corp., Tokyo, Japan), which is inserted through the working channel of the conventional bronchoscope towards to the target pulmonary lesion. It allows a $360^{\circ}$ 
surrounding view of the parenchyma. It also helps to identify the correct bronchus of the lesion, based on echogenicity differences between bronchus, lesion and normal tissue. ${ }^{(5,8)}$ In this way, the development of RPEBUS has emerged to improve bronchoscopy diagnostic sensitivity and accuracy for pulmonary nodules and masses. ${ }^{(8)}$

Radial-probe EBUS should be performed under fluoroscopy guidance to help evaluating the target lesion. Cytologic examination and transbronchial biopsies (brush and peripheral transbronchial needle aspiration) can be performed during the procedure, and the samples can be sent for microbiological, cytological and histological analysis, depending on clinical, radiological and cytological evaluation. ${ }^{(8,9)}$ For instance, figure 3 shows an upper left lobe nodule in a 72-year-old female smoker patient. We performed a bronchoscopy with radial EBUS and fluoroscopy (Figures 4 and 5). The final diagnosis was lung adenocarcinoma.

Some factors, such as nodule size and capacity to visualize and locate the probe inside the lesion may affect the diagnostic yield of RP-EBUS. Our preliminary experience with RP-EBUS in Brazil showed good sensitivity for both nodules and masses (74.1 and $92 \%$, respectively). ${ }^{(8)}$

EBUS-TBNA and RP-EBUS are safe procedures with low complication rates. The most common complication in EBUS-TBNA is damage to equipment during needle manipulation. Other complications like bleeding and infectious are rare. In RP-EBUS the complications are pneumothorax and bleeding, ranging from 1 a $4 \%$ and 3 a $5 \%$, respectively, in most series. ${ }^{(9,10)}$

Table 1 displays the summary of characteristics of RP-EBUS and EBUS-TBNA.

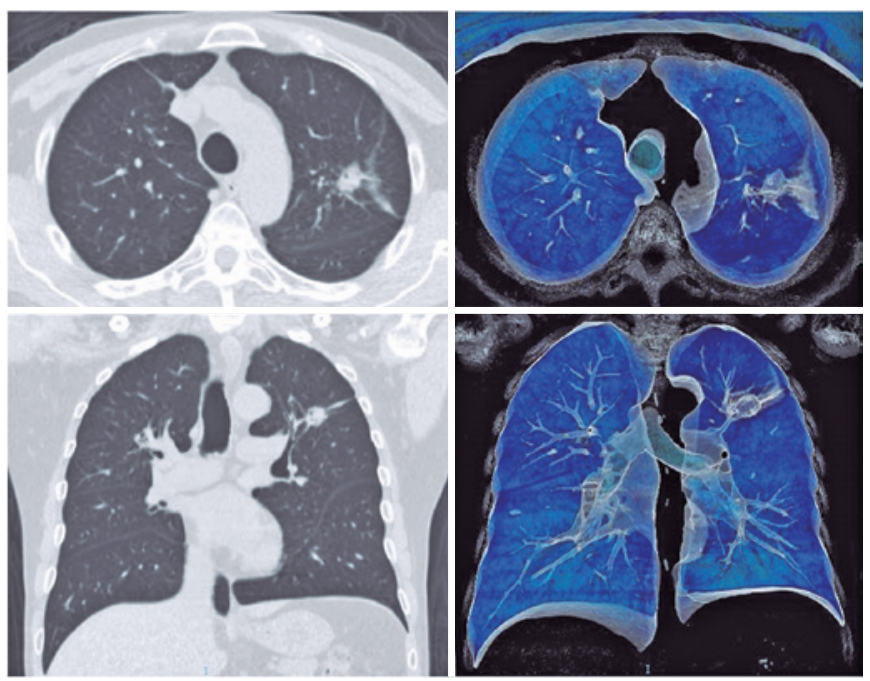

Figure 3. Upper left lobe nodule

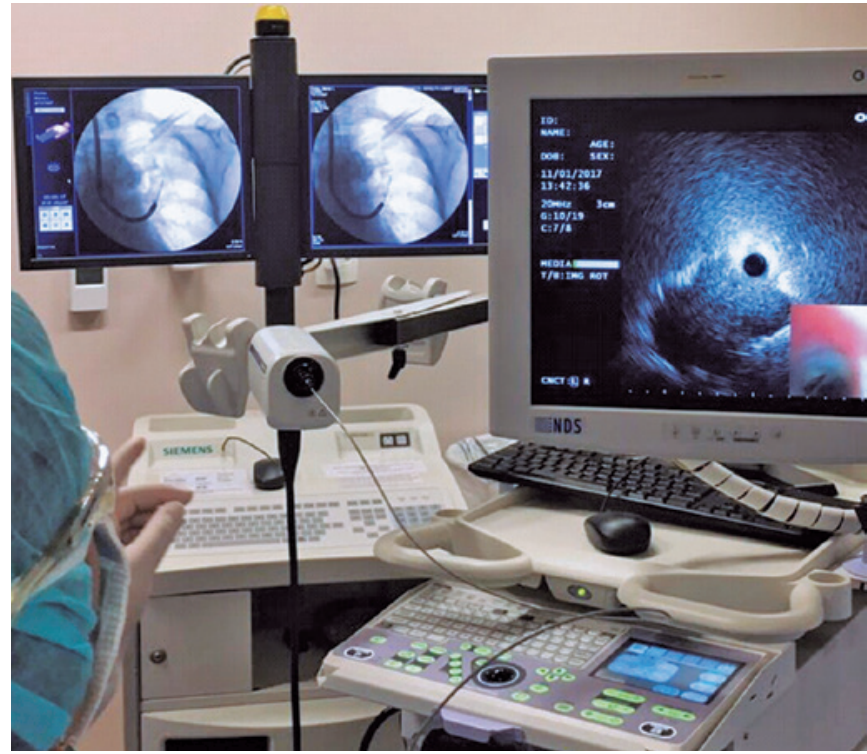

Figure 4. Bronchoscopy with radial endobronchial ultrasound and fluoroscopy for better visualization and performance of transbronchial biopsy of the pulmonary nodule in the upper left lung lobe
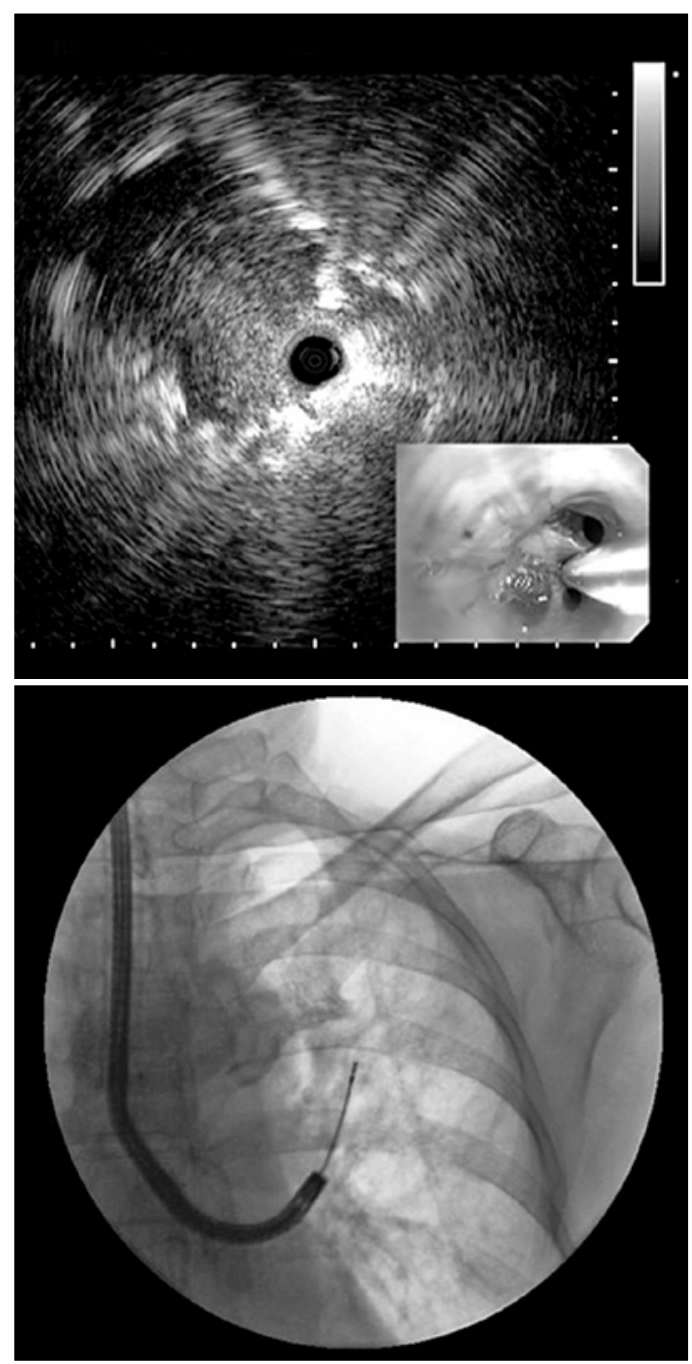

Figure 5. Radial endobronchial ultrasound and transbronchial biopsy guided by fluoroscopy 
Table 1. Summary of characteristics of radial-probe endobronchial ultrasound and endobronchial ultrasound-transbronchial needle aspiration

\begin{tabular}{|c|c|c|}
\hline Topics & RP-EBUS & EBUS-TBNA \\
\hline \multirow[t]{2}{*}{ Characteristics } & $\begin{array}{l}\text { Conventional bronchoscopy } \\
\text { with flexible probe }\end{array}$ & $\begin{array}{l}\text { Dedicated bronchoscope with } \\
\text { EBUS in the tip }\end{array}$ \\
\hline & No doppler function & Doppler function \\
\hline Target & $\begin{array}{l}\text { Peripheral lung lesions } \\
\text { (nodules and masses) }\end{array}$ & $\begin{array}{l}\text { Mediastinal and hilar lesions } \\
\text { (staging and restaging lung cancer, } \\
\text { other neoplasms, inflammatory and } \\
\text { infectious lesions) }\end{array}$ \\
\hline Sensitivity & $\begin{array}{l}70 \text { to } 92 \% \text {, depending on the } \\
\text { characteristics of the lesion }\end{array}$ & $84-96 \%$ \\
\hline \multirow{3}{*}{$\begin{array}{l}\text { Associated } \\
\text { techniques }\end{array}$} & Fluoroscopy, guide sheath & TBNA \\
\hline & TBLB, TBNA, BAL & ROSE \\
\hline & ROSE & \\
\hline \multirow[t]{2}{*}{ Complications } & Pneumothorax (1-4\%) & Overall $(1.4 \%)$ \\
\hline & Bleeding (3-5\%) & $\begin{array}{l}\text { Perforation by bronchoscope } \\
\text { working channel }\end{array}$ \\
\hline
\end{tabular}

RP: radial-probe; EBUS: endobronchial ultrasound; TBNA: transbronchial needle aspiration; TBLB: transbronchial lung biopsy; BAL: bronchoalveolar lavage; ROSE: rapid on-site evaluation.

\section{CONCLUSION}

Radial and convex endobronchial ultrasound is a safe procedure, with low complication rate and good sensitivity for both nodules and masses.

\section{AUTHORS' INFORMATION}

Costa Jr. AS: http://orcid.org/0000-0003-0912-2330

Palomino AL: http://orcid.org/0000-0002-1152-0066

Suzuki I: http://orcid.org/0000-0002-4660-8738

Scordamaglio PR: http://orcid.org/0000-0001-8971-5333

Gregorio MG: http://orcid.org/0000-0002-2526-4606

Jacomelli M: http://orcid.org/0000-0001-8657-458X

\section{REFERENCES}

1. Figueiredo VR, Jacomelli M, Rodrigues AJ, Canzian M, Cardoso PF, Jatene FB. Current status and clinical applicability of endobronchial ultrasound-guided transbronchial needle aspiration. J Bras Pneumol. 2013;39(2):226-37. Review.

2. Rusch VW, Asamura H, Watanabe H, Giroux DJ, Rami-Porta R, Goldstraw P, et al. Members of IASLC Staging Committee.The IASLC lung cancer staging project: a proposal for a new international lymph node map in the forthcoming seventh edition of the TNM classification for lung cancer. J Thorac Oncol. 2009;4(5):568-77.

3. van der Heijden EH, Casal RF, Trisolini R, Steinfort DP, Hwangbo B, Nakajima T, Guldhammer-Skov B, Rossi G, Ferretti M, Herth FF, Yung R, Krasnik M; World Association for Bronchology and Interventional Pulmonology, Task Force on Specimen Guidelines. Guideline for the acquisition and preparation of conventional and endobronchial ultrasound-guided transbronchial needle aspiration specimens for the diagnosis and molecular testing of patients with known or suspected lung cancer. Respiration. 2014;88(6):500-17. Review.

4. Zhang R, Ying K, Shi L, Zhang L, Zhou L. Combined endobronchial and endoscopic ultrasound-guided fine needle aspiration for mediastinal lymph node staging of lung cancer: a meta-analysis. Eur J Cancer. 2013;49(8):1860-7. Review.

5. Dong X, Qiu X, Liu Q, Jia J. Endobronchial ultrasound-guided transbronchial needle aspiration in the mediastinal staging of non-small cell lung cancer: a meta-analysis. Ann Thorac Surg. 2013;96(4):1502-7.

6. Figueiredo VR, Cardoso PF, Jacomelli M, Demarzo SE, Palomino AL, Rodrigues $\mathrm{AJ}$, et al. Endobronchial ultrasound-guided transbronchial needle aspiration for lung cancer staging: early experience in Brazil. J Bras Pneumol. 2015; $41(1): 23-30$.

7. Santos RS, Jacomelli M, Franceschini JP, Suzuki I, Costa AD Jr., Shiang C, et al. Endobronchial ultrasound-guided transbronchial needle aspiration (EBUS-TBNA) in diagnosis of mediastinal lesions. einstein (São Paulo). 2018; 16(2):13-17.

8. Jacomelli M, Demarzo SE, Cardoso PF, Palomino AL, Figueiredo VR. Radialprobe EBUS for the diagnosis of peripheral pulmonary lesions. J Bras Pneumol. 2016;42(4):248-53. Erratum in: J Bras Pneumol. 2017;43(1):78.

9. Ali MS, Trick W, Mba BI, Mohananey D, Sethi J, Musani Al. Radial endobronchial ultrasound for the diagnosis of peripheral pulmonary lesions: a systematic review and meta-analysis. Respirology. 2017;22(3):443-53. Review.

10. Eapen GA, Shah AM, Lei X, Jimenez CA, Morice RC, Yarmus L, Filner J, Ray C, Michaud G, Greenhill SR, Sarkiss M, Casal R, Rice D, Ost DE; American College of Chest Physicians Quality Improvement Registry, Education, and Evaluation (AQulRE) Participants. Complications, consequences, and practice patterns of endobronchial ultrasound-guided transbronchial needle aspiration: Results of the AQulRE registry. Chest. 2013;143(4):1044-53. 